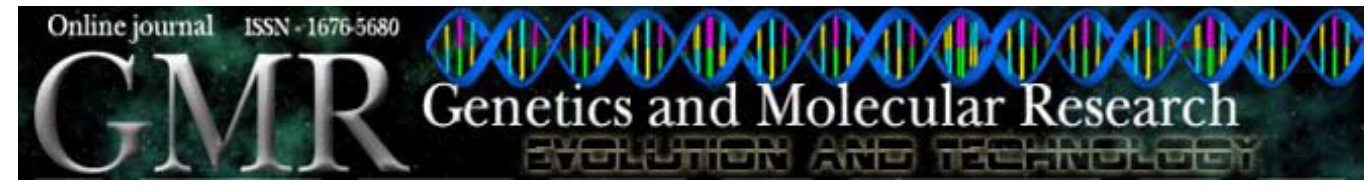

\title{
DNA extraction from hair shafts of wild Brazilian felids and canids
}

\author{
C.C. Alberts ${ }^{1}$, J.T. Ribeiro-Paes ${ }^{1}$, G. Aranda-Selverio ${ }^{2}$, \\ J.R. Cursino-Santos ${ }^{6}$, V.R. Moreno-Cotulio ${ }^{3}$, A.L.D. Oliveira ${ }^{4}$, \\ B.F.M.M. Porchia ${ }^{1}$, W.F. Santos ${ }^{5}$ and E.B. Souza ${ }^{1}$ \\ ${ }^{1}$ Departamento de Ciências Biológicas, \\ Faculdade de Ciências e Letras de Assis, Universidade Estadual Paulista, \\ Assis, SP, Brasil \\ ${ }^{2}$ Departamento de Física, Química e Biologia, \\ Faculdade de Ciências e Tecnologia, Universidade Estadual Paulista, \\ Presidente Prudente, SP, Brasil \\ ${ }^{3}$ Instituto de Ciências da Natureza, Universidade Federal de Alfenas, \\ Alfenas, MG, Brasil \\ ${ }^{4}$ Departamento de Ciências da Saúde, Universidade Paulista, \\ Campus de Assis, SP, Brasil \\ ${ }^{5}$ Departamento de Biologia, Faculdade de Filosofia, \\ Ciências e Letras de Ribeirão Preto, \\ Universidade de São Paulo, Ribeirão Preto, SP, Brasil \\ ${ }^{6}$ Departamento de Genética, Faculdade de Medicina de Ribeirão Preto, \\ Universidade de São Paulo, Ribeirão Preto, SP, Brasil \\ Corresponding author: C.C. Alberts \\ E-mail: calberts@assis.unesp.br/jtrpaes@yahoo.com.br
}

Genet. Mol. Res. 9 (4): 2429-2435 (2010)

Received August 8, 2010

Accepted November 11, 2010

Published December 21, 2010

DOI 10.4238/vol9-4gmr1027

ABSTRACT. Wild felids and canids are usually the main predators in the food chains where they dwell and are almost invisible to behavior and ecology researchers. Due to their grooming behavior, they tend to swallow shed hair, which shows up in the feces. DNA found in hair shafts can be used in molecular studies that can unravel, for instance, genetic variability, reproductive mode and family structure, and in some 
species, it is even possible to estimate migration and dispersion rates in given populations. First, however, DNA must be extracted from hair. We extracted successfully and dependably hair shaft DNA from eight wild Brazilian felids, ocelot, margay, oncilla, Geoffroy's cat, pampas cat, jaguarundi, puma, and jaguar, as well as the domestic cat and from three wild Brazilian canids, maned wolf, crab-eating fox, and hoary fox, as well as the domestic dog. Hair samples came mostly from feces collected at the São Paulo Zoo and were also gathered from non-sedated pet or from recently dead wild animals and were also collected from museum specimens. Fractions of hair samples were stained before DNA extraction, while most samples were not. Our extraction protocol is based on a feather DNA extraction technique, based in the phenol:chloroform:isoamyl alcohol general method, with proteinase $\mathrm{K}$ as digestive enzyme.

Key words: Felidae; Canidae; Hair shaft DNA extraction

\section{INTRODUCTION}

Generally, due to their nocturnal and/or crepuscular habits and secretive way of life, Carnivore mammals cannot be easily seen in the wild, which makes it difficult to study their behavior and ecology. On the other hand, they leave typical signs, such as footprints, feces and hairs, which provide useful information on these topics. Felids and canids are the top predators of almost all food chains where they dwell. As they display grooming behaviors, some hairs tend to be swallowed, going through the digestive tract and showing up in their feces. Morphologic and molecular studies of these hairs can provide important information about the animal, such as its species, territory, population size, relatedness to other cospecifics in the area, social behavior, and genetic variability of the population, among others (Waits and Paetkau, 2005).

Surveys about mammals in the wild, based on vestiges such as the ones discussed above, can be complemented with the aid of hair traps placed in strategic positions such as openings of dens, near food intentionally placed by the observer and in nests (Baker, 1980; Quadros, 2002). Samples collected in zoo cages can also be analyzed like this, and museums containing mammal collections can also be a rich source of data from animals living in the present or in the recent past (Leeton et al., 1993). Additionally, ancient DNA in hair shafts seems to be more protected against denaturation than in other sources, since, for example, even 50,000-year-old useful DNA was found in mammoth hair shafts (Gilbert at al., 2007). If this is true for such a long period of time, it must be even better for samples lasting in the wild for moderate time spans, such as one season long or even for a year or two in dry and/or cold regions.

DNA extraction and purification techniques have been developed for various types of tissues in order to take advantage of genetic studies, where their use is widespread for organic materials such as skin, peripheral blood, feathers, and hair bulbs and hair shafts.

Hairs are keratinized epidermal elements that cover the body of mammals, which is one of their distinguishing characters; hair's main functions are thermoregulation and protection. From a histological point of view, hair can be divided into four components: medulla, cuticle, cortex, and pigment granules. The medulla can be found in the central area of hairs and is formed by aggregations of cells contracted between spaces filled with air (Tobin, 2005). 
In short, hairs are essentially extra-cellular projections made up of keratin, air sacs (medulla) and melanin granules. Melanin is a potent polymerase chain reaction (PCR) inhibitor (Wilson et al., 1995), and thus making DNA typing more difficult (Higuchi et al., 1988; Wilson et al., 1995; Graham, 2007).

In the shaft of hairs, DNA is present in small amount and tends to decrease in concentration along its extension (Heywood et al., 2003). Some authors considered that DNA would be totally degraded during hair keratinization. Thus, it would not be possible to extract it from there, but this was proved wrong (Higuchi et al., 1988; Schreiber et al., 1988; Wilson et al., 1995; Jehaes et al., 1998; Nozawa et al., 1999; Takayanagi et al., 2003; Wetton et al., 2003; Tully et al., 2004; Pfeiffer et al., 2004). In the last years, DNA extraction from human hair shafts has been extensively used in forensics (Chang et al., 2002).

There is a variety of uses for DNA extracted from hair shafts and different techniques can be employed in its studies. A review on DNA-based techniques for wildlife researchers can be found in a report by Waits and Paetkau (2005). Among those techniques using DNA is the detection of genetic variability or molecular biodiversity, which can be a tool for ecologists and ethologists to identify animal remains, to analyze reproductive mode and family structure in some species and even to estimate migration and dispersion rates in a given population. Some techniques to identify molecular markers can be used with the DNA extracted for population studies, for example, in DNA fingerprinting, RFLP (restriction fragment length polymorphism) and RAPD (random amplified polymorphic DNA).

With DNA fingerprinting, it is possible to examine the level of relatedness among humans. It would be ideal to do the same routinely with other animals, especially when investigating the social behavior of a given animal species. To get the genetic material to do this test, blood or other tissues are usually extracted from the donor. However, such an invasive extraction method for animals being monitored in the wild or in zoos could jeopardize ongoing behavior studies, because it would be necessary to capture the animal and sedate it, extract the material, and then release the animal. Therefore, the very social equilibrium being studied could be altered, invalidating the results. The use of hairs found in feces or in hair traps can avoid such problems.

Thus, the aim of the present study was to optimize the general method of DNA isolation from many biological samples to the limited samples as one or few hair shafts of wild and domestic felid and canid species, in an efficient and dependable way.

\section{MATERIAL AND METHODS}

\section{Material}

Hair was collected from different felid and canid species and from different sources. As can be seen in Table 1, samples of felids came mostly from feces collected at the São Paulo Zoo (Fundação Parque Zoológico de São Paulo), where every feces sample was identified with the zoo cage in which it was collected. Prior to its use in this DNA extraction study, each single hair was cleaned up with water and kitchen detergent. In addition, samples from domestic cats were gathered from two non-sedated pet animals of no defined breed. Samples from one single felid species, Puma yagouaroundi, Jaguarundi, were collected from two specimens of the MZUSP (Museu de Zoologia da Universidade de São Paulo). Canid hair samples 
were mainly collected from recently (and accidentally) dead animals found in two Brazilian National Parks. Apart from these sources, a second set of samples from a maned wolf were collected from a sedated animal, in one of the parks. In the same way as for the domestic cats, samples from domestic dogs were gathered from two non-sedated pet animals, also of no defined breed.

Table 1. Species used in this study, indicating type of biologic source of hair and its origin.

\begin{tabular}{lll}
\hline Species & Biologic source & Origin/Institution \\
\hline Ocelot (Leopardus pardalis) & Feces & São Paulo Zoo \\
$\begin{array}{l}\text { Margay (Leopardus wiedii) } \\
\text { Oncilla (Leopardus tigrinus) } \\
\text { Geoffroy's cat (Oncifelis geoffroyi) }\end{array}$ & \\
$\begin{array}{l}\text { Pampas cat (Oncifelis colocolo) } \\
\text { Puma (Puma concolor) }\end{array}$ & & \\
Jaguar (Panthera onca) & & \\
Jaguarundi (Puma yagouaroundi) & Feces/Museum & \\
Crab-eating fox (Cerdoncyon thous) & Recently dead specimen & Eaulo Zoo/MZUSP \\
Hoary fox (Lycalopex vetutus) & Sedated specimen & \\
Maned wolf (Chrysocyon brachyurus) & & \\
Domestic cat (Felis catus) & & Domestic owner \\
Domestic dog (Canis familiaris) & Non-sedated specimen & \\
\hline
\end{tabular}

\section{Isolation of genetic material}

To ensure that the genetic material would be isolated exclusively from hair shafts, the hair proximal end, with hair bulbs, was cut off. Samples with 1 to 3 individual hairs were placed in $1.5-\mathrm{mL}$ microtubes containing $70 \%$ ethanol for $56 \mathrm{~h}$. Samples were then placed on Petri dishes and incubated at $40^{\circ} \mathrm{C}$ for $5 \mathrm{~min}$, for complete ethanol evaporation. Afterward, the chemical/biochemical steps of DNA extraction were carried out.

Samples were then placed in Eppendorf microtubes containing: $300 \mu \mathrm{L} 1 \mathrm{X}$ TNE (50 mM Tris-HCl, 100 mM NaCl, 6.3 mM EDTA, pH 7.5); $30 \mu \mathrm{L} 1 \mathrm{mM}$ Tris-HCl, pH 7.5; $10 \mu \mathrm{L}$ $10 \mathrm{mg} / \mathrm{mL}$ proteinase $\mathrm{K}$ solution (Invitrogen); $7 \mu \mathrm{L} 0.5 \mathrm{M} \mathrm{CaCl}_{2} ; 10 \mu \mathrm{L} \mathrm{25 \%}$ SDS (2.5 g SDS in $10 \mathrm{~mL}$ distilled water), and $100 \mu \mathrm{L} \mathrm{2-mercaptoethanol.}$

The Eppendorf microtubes were vortexed for reagent and sample homogenization. Afterward, the tubes were transferred to a bath at $55^{\circ} \mathrm{C}$ for $48 \mathrm{~h}$, and vortexed again (for additional homogenization) every $12 \mathrm{~h}$. Next, $300 \mu \mathrm{L}$ phenol:chloroform:isoamyl alcohol $(25: 24: 1)$ was added, followed by centrifugation at $9445 \mathrm{~g}$ in a HSIANGTAI centrifuge for $15 \mathrm{~min}$. The supernatant was transferred to a fresh tube to which was added $300 \mu \mathrm{L}$ cold $100 \%$ ethanol (about $-6^{\circ} \mathrm{C}$ ) and $50 \mu \mathrm{L} 3 \mathrm{M}$ sodium acetate $\left(\mathrm{NaC}_{2} \mathrm{H}_{3} \mathrm{O}_{2}\right.$ ), pH 5.2 (4082 g sodium acetate in $10 \mathrm{~mL}$ distilled water). Tubes were then resubmitted to centrifugation at $9445 \mathrm{~g}$ for $15 \mathrm{~min}$. The pellet was washed twice with $300 \mu \mathrm{L}$ cold $100 \%$ ethanol (about $-6^{\circ} \mathrm{C}$ ). After incubation at room temperature, the DNA was eluted in $30 \mu \mathrm{L}$ TE, pH 8.0 (10 mM Tris- $\mathrm{HCl}, \mathrm{pH} 8.0 ; 1 \mathrm{mM}$ EDTA), and left at $37^{\circ} \mathrm{C}$ for $40 \mathrm{~min}$.

\section{Quantification}

Extracted DNA material was quantified in a ULTROSPEC 1100 PRO spectrophotometer. 


\section{Testing number of individual hairs}

Although for all species 3 to 5 samples were tested, quantification was performed only once per condition, where the sample was chosen randomly. The exception was the museum material, which was very scarce, and thus, we could only run one test.

\section{RESULTS AND DISCUSSION}

We succeeded in our attempt to extract DNA from hair shafts from domestic and wild species of Brazilian felids and canids, and the quantification results can be seen in Table 2 .

\begin{tabular}{|c|c|}
\hline Species & DNA $(n g / \mu \mathrm{L})$ \\
\hline \multicolumn{2}{|l|}{ Felids } \\
\hline Domestic cat (Felis catus) & 599.1 \\
\hline Ocelot (Leopardus pardalis) & 327.9 \\
\hline Margay (Leopardus wiedii) & 282.0 \\
\hline Oncilla (Leopardus tigrinus) & 404.1 \\
\hline Geoffroy's cat (Oncifelis geoffroyi) & 377.3 \\
\hline Pampas cat (Oncifelis colocolo) & 529.5 \\
\hline Jaguarundi (Puma yagouaroundi) & 575.6 \\
\hline Jaguarundi (Puma yagouaroundi) ${ }^{1}$ & 593.0 \\
\hline Puma (Puma concolor) & 332.9 \\
\hline Jaguar (Panthera onca) & 419.5 \\
\hline \multicolumn{2}{|l|}{ Canids } \\
\hline Domestic dog (Canis familiaris) & 296.3 \\
\hline Domestic dog (Canis familiaris) stained & 494.8 \\
\hline Crab-eating fox (Cerdoncyon thous) & 54.1 \\
\hline Hoary fox (Lycalopex vetutus) & 95.5 \\
\hline Maned wolf (Chrysocyon brachyurus $)^{2}$ & 360.9 \\
\hline Maned wolf (Chrysocyon brachyurus) stained ${ }^{3}$ & 517.4 \\
\hline
\end{tabular}

${ }^{1}$ Museum specimen; ${ }^{2}$ Sedated specimen; ${ }^{3}$ Recently dead specimen.

Although having found several protocols for DNA extraction from hair shafts in the literature (for example, Higuchi et al., 1988; Schreiber et al., 1988; Wilson et al., 1995; Jehaes et al., 1998; Nozawa et al., 1999; Chang et al., 2002; Takayanagi et al., 2003; Wetton et al., 2003; Pfeiffer et al., 2004; Tully et al., 2004), we obtained our results using a method originally meant to extract DNA from feathers (Miyaki, 1996) rather than from hairs, upon which our improved protocol was based.

We tested hairs from a variety of sources in order to compare results. Museum material, for instance, could have suffered damage due to the chemicals involved in skin conservation, and the same could have been true for hair in feces, which passed through digestive tracts, being exposed to chemical and biochemical processes. In both cases, we showed that there were no negative influences on the results. We also stained some hair samples. Quantification showed that the staining of hairs did not reduce the amounts of DNA extracted from those samples. On the contrary, staining seemed to improve results of the protocol. This outcome can possibly be good news for further manipulation of extracted DNA, since melanin, which is removed by staining, tends to inhibit Taq polymerase in PCR (Takayanagi et al., 2003).

It can be said that the success of our technique is due to an array of factors, including the relatively small amount of hairs in the sample. We tested different quantities, and the best results, in terms of total DNA extracted, were with 2 to 3 individual hairs per sample, about $10 \mathrm{~cm}$ in 
length when summed up, although weight and thickness of hairs varied widely among species.

Comparing to the original protocol of Miyaki (1996), our procedure was also altered in reference to the time and amount of reagents used. In this aspect, the step of bathing the samples with $70 \%$ ethanol was crucial, since it allowed further decontamination of hairs and softening of the protein structure of the hair cortex, which involves the medulla.

To enhance the access of reagents to the DNA preserved in the shaft, we added 2-mercaptoethanol, since this reagent degrades disulfide bonds in hair structure, and when compared to the use of the extraction buffer without it, this method showed better results.

We also added calcium chloride $\left(\mathrm{CaCl}_{2}\right)$ to the extraction buffer, which facilitated the process, since it activates proteinase $\mathrm{K}$ (Pfeifer et al., 2004), which eases keratin digestion. Calcium acetate $\left(\mathrm{CaC}_{2} \mathrm{H}_{3} \mathrm{O}_{2}\right), 0.3 \mathrm{M}, \mathrm{pH} 5.2$, was added to enhance precipitation of DNA.

According to Takayanagi et al. (2003) and Graham (2007), shed hairs, which were swallowed during self-grooming, are in the telogen phase and cells in the shaft contain little nuclear DNA. On the other hand, shafts contain high quantities of mtDNA (Lutz et al., 1996). Nevertheless, Nozawa et al. (1999) demonstrated that it is indeed possible to extract nuclear DNA from hair shafts. They used CTAB to precipitate DNA and used a technique called "nested PCR", which can be viewed as duplicated PCR. According to the authors, the total extracted DNA is sufficient to run nuclear DNA-based relatedness recovery methods.

\section{CONCLUSIONS}

We adapted and improved a method originally meant to extract DNA from feather bulbs to use it with hair shafts. Testing our procedure with wild Brazilian felids and canids, along with domestic ones, we were able to show that, whatever the source, feces or skin of recently dead or living animals or even from museum specimens, stained or not, DNA could be consistently extracted from hair shafts.

The results suggest that DNA extracted by our method can be used for various ecological and ethological purposes, depending on the research aims, as well on what techniques the researcher employ to make use of nuclear or mitochondrial DNA.

\section{ACKNOWLEDGMENTS}

We wish to thank Iris Amati Martins and Juliana de Luca for providing wild felid and canid hair samples, as well as the Fundação Parque Zoológico de São Paulo and Museu de Zoologia da Universidade de São Paulo, original sources of most of those samples. Research supported in part by FAPESP (Fundação de Amparo à Pesquisa do Estado de São Paulo) and FUNDUNESP (Fundação para o Desenvolvimento da UNESP).

\section{REFERENCES}

Baker BW (1980). Hair-catchers aid in identifying mammalian predators of ground-nesting birds. Wildl. Soc. Bull. 8: 257-259.

Chang HW, Yen CY, Liu SY, Singer G, et al. (2002). Genotype analysis using human hair shaft. Cancer Epidemiol. Biomarkers Prev. 11: 925-929.

Gilbert MT, Tomsho LP, Rendulic S, Packard M, et al. (2007). Whole-genome shotgun sequencing of mitochondria from ancient hair shafts. Science 317: 1927-1930. 
Graham EAM (2007). DNA Reviews: hair. Forensic Sci. Med. Pathol. 3: 133-137.

Heywood DM, Skinner R and Cornwell PA (2003). Analysis of DNA in hair fibers. J. Cosmet. Sci. 54: 21-27.

Higuchi R, von Beroldingen CH, Sensabaugh GF and Erlich HA (1988). DNA typing from single hairs. Nature 332: 543-546.

Jehaes E, Gilissen A, Cassiman JJ and Decorte R (1998). Evaluation of a decontamination protocol for hair shafts before mtDNA sequencing. Forensic Sci. Int. 94: 65-71.

Leeton P, Christidis L and Westerman M (1993). Feathers from museum bird skins: a good source of DNA for phylogenetic studies. The Condor 95: 465-466.

Lutz S, Weisser HJ, Heizmann J and Pollak S (1996). mtDNA as a tool for identification of human remains. Identification using mtDNA. Int. J. Legal Med. 109: 205-209.

Miyaki CY (1996). Um Estudo Filogenético de Psitacídeos (Psittaciformes, Aves) Baseado em Seqüências de Genes Mitocondriais. Doctoral thesis, Instituto de Biociências. Universidade de São Paulo, São Paulo.

Nozawa H, Yamamoto T, Uchihi R, Yoshimoto T, et al. (1999). Purification of nuclear DNA from single hair shafts for DNA analysis in forensic sciences. Leg. Med. 1: 61-67.

Pfeiffer I, Volkel I, Taubert H and Brenig B (2004). Forensic DNA-typing of dog hair: DNA-extraction and PCR amplification. Forensic Sci. Int. 141: 149-151.

Quadros J (2002). Identificação Microscópica de Pêlos de Mamíferos Brasileiros e Sua Aplicação no Estudo da Dieta de Carnívoros. Doctoral thesis, Universidade Federal do Paraná, Londrina.

Schreiber A, Amtmann E, Storch V and Sauer G (1988). The extraction of high-molecular-mass DNA from hair shafts. FEBS Lett. 230: 209-211.

Takayanagi K, Asamura H, Tsukada K, Ota M, et al. (2003). Investigation of DNA extraction from hair shafts. Int. Congress Series 1239: 759-764.

Tobin DJ (2005). The Human Hair Fiber. In: Hair in Toxicology - An Important Biomonitor (Tobin DJ, ed.). The Royal Society of Chemistry, Cambridge, 34-56.

Tully G, Barritt SM, Bender K, Brignon E, et al. (2004). Results of a collaborative study of the EDNAP group regarding mitochondrial DNA heteroplasmy and segregation in hair shafts. Forensic Sci. Int. 140: 1-11.

Waits LP and Paetkau D (2005). Noninvasive genetic sampling tools for wildlife biologists: a review of applications and recommendations for accurate data collection. J. Wildl. Man. 69: 1419-1433.

Wetton JH, Higgs JE, Spriggs AC, Roney CA, et al. (2003). Mitochondrial profiling of dog hairs. Forensic Sci. Int. 133: 235-241.

Wilson MR, Polanskey D, Butler J, DiZinno JA, et al. (1995). Extraction, PCR amplification and sequencing of mitochondrial DNA from human hair shafts. Biotechniques 18: 662-669. 